\title{
Entrepreneurship in Afghanistan and the Leading Effect of International Indices in the Development of Entrepreneurship in Afghanistan
}

\author{
Ahadzai AHMADI \\ Trakya University \\ Institute of Social Sciences \\ Business Administration Graduate Student \\ Edirne-Turkey \\ Gülsevim YUMUK GÜNAY, Ph.D. \\ Associate Professor \\ Trakya University, Applied School of Sciences \\ Department of Tourism and Hotel Management \\ Edirne-Turkey \\ Tülay DEMIRALAY, Ph.D. \\ Assistant Professor \\ Trakya University \\ Keşan Yusuf Çapraz School of Applied Sciences \\ Department of Banking and Insurance \\ Keşan-Turkey
}

\begin{abstract}
Entrepreneurship is known to be one of the most important power sources for developing countries and improving their economies. Many developed countries owe their strong economies to entrepreneurial activities in their countries. The period of foreign and civil wars in Afghanistan and the constant change of government have deeply and negatively affected the country's economy and entrepreneurial activities in that country. The development of Afghan economy and entrepreneurship depends on the entrepreneurial investments and supports to be performed in the country. For this purpose, the place of Afghanistan in international indices was examined and the recommendations about the development of entrepreneurship in Afghanistan were tried to be presented considering the relations between the indices. In the study, simple linear regression analysis was applied to test the causality relationship between EGovernment Development level, Logistics Performance level and Information and Communication Technology Development level which are considered to be effective on the ease of doing business. According to the research results, it has been seen that the investments on information and communication technologies, logistics performance and E-Government development investments significantly and positively affect the ease of doing business.
\end{abstract}

Keywords: Afghanistan, Entrepreneurship, International Indices

\section{Introduction}

Entrepreneurship is an important phenomenon that needs to be considered and studied in the context of revitalization of national economies, increase of employment opportunities and of welfare level. Entrepreneurship can be considered that any individual sets up her/his own business in the individual sense, while any company becomes innovative, pioneer and competitive and takes a risk in the organizational sense.

Richard Cantillon was the first man to define the entrepreneurship in 1755. Cantillon explained entrepreneurship by identifying entrepreneur and expressed it as the activities s/he performs to gain profit (Demiroglu, 2007:2). Mueller and Thomas (2000:52) defined entrepreneurship as a process of action to see and evaluate the existing opportunities. Coulter (2001:4) also considered economic and social risks in this process and implied to produce services. Bird (1998:442) has emphasized that innovation, change and technology should be followed through entrepreneurship.

Formorethan 30 years, Afghanistan has experienced conflict and war, and has been almost completely ruined. These negative conditions caused the destruction of the daily life and physical infrastructure and the interruption of the economic progress. 
The political, economic and social transformation began in the country after the fall of the Taliban regime, 2001, This transformation may lead Afghanistan to be considered a land of opportunity for both domestic and foreign entrepreneurs. Specifically "Economic Governance", which is the coordination of economic and financial policies in the EU, played an important role in strengthening the private sector of Afghanistan, collaborating with the people, establishing the private sector, contributing to economic growth and developing the infrastructure of Afghanistan (Haidary, 2016: 27). It has been observed that these developments do not make big changes the place of Afghanistan in international indices but create small improvements.

\section{Domestic And Foreign Entrepreneurship In Afghanistan}

It is of great importance that the Afghan government strives to strengthen private sector entrepreneurship, increase exports and create job opportunities in Afghanistan. The private-public cooperation law was approved by the Afghan Assembly in 1996 in order to increase investments in the country. This law also includes certain facilities for foreign and domestic entrepreneurs (https://www.aydinlik.com.tr/, access: 08.03.2018).

Supporting effortstocreate job opportunities in the country, USAID (The United States Agency for International Development) strives for economic growth that is critical to the long-term security and social-economic stability of the country. USAID undertakes tasks such as promoting cross-border trade, providing access to credit with Afghan financial institutions, strengthening industrial value chains, supporting access to regional-international markets and increasing the entrepreneurship of the new domestic/foreign private sector and providing technical support for legal and regulatory reforms (USAID, 2018: 4).

Domestic investors in the country have priority opportunities compared to foreign investors due to their advantages such as having qualified personnel in various fields, customs (for import and export) facilities, living conditions and security measures. In general, domestic investors can more easily access to (manager, professional) technician and qualified workers than foreign investors. This advantage of local businesses is mainly due to the fact that they have the existing informal communication networks, which provides them access to the high-quality and cost-effective personnel source (Horizons, 2005: 52-53).

Local companies are primarily involved in commercial transportation as compared to foreign companies. They understand and analyze Afghanistan's quality of life factors (cost of living, security, health and leisure activities) better than foreign investors, and have more motivation for the revival and recovery of Afghanistan from its recent downturns (Popal, 2012: 6-10). Therefore, the government has recognized that the entrepreneurial motivation and the quality of infrastructure (Telecommunication, electric power, water and sewage) should be increased in the country (Horizons, 2005: 53) and a number of possibilities are being offered by law.

Entrepreneurial activities can be shadowed by the confusion of legal structure in the presence of foreign investors in Afghanistan. The legal structure of Afghanistan is not yet mature and the regulations of the private sector have not yet been implemented. Thus, the current official law, Sharia rules and traditional legal rules are intermingled (Office of the Commercial Counsellor in Kabul, 2017: 39). These uncertainties in the rules of law eliminate the element of trust for foreign entrepreneurs and lead them to shift their investments to different countries.

In the last ten years, Afghanistan has aimed and striven to establish its own telecommunication network, which increases the ease of doing business in the country as a result of the assistance of foreign countries. This has been an opportunity to improve the communication and logistics infrastructure, which are important for entrepreneurship. These first initiatives in the field of telecommunications are the beginning of new investments and the entry of foreign capital into the country (Haqzoy, 2017: 29). In particular, telecommunications investments in the banking sector play an important role in development and economic growth in Afghanistan. It has developed a platform for faster, safer and more affordable banking services (Haqzoy, 2017: 31). E-banking service has become an important investment opportunity for foreign enterprises in Afghanistan which is trying to improve the telecommunication network (Haqzoy, 2017: 29-32).

Afghanistan has made regulations in order to promote domestic and foreign investors as follows:

1. The Afghan government has accepted the declaration under the name of investment legislation in order to provide incentives to domestic and foreign investors and to protect their investors, in terms of investment opportunities. The purpose of this legislation is promote economic development in the country, to expand the labor market, to increase national welfare, to raise the standard of living of the population and to help rebuild Afghanistan.

2. The use of tangible and intangible fixed assets in cash and credit form has not been approved by the High Investment Commission and also domestic and foreign natural or legal investments have been restricted in accordance with this law. 
3. According to the provisions of this legislation and the Commercial Code, qualified domestic or real, legal foreign assets can invest in all sectors of the economy.

4. The State has no right to seize domestic law or foreign investment for a period as required by law and a court decision with appropriate jurisdiction.

5. The High Investment Commission will be the focal point for government investment policies.

6. The High Investment Commission will have two separate representative seats for the private sector for one year. The Chamber of Commerce will choose these representatives within the first year. Then, investors will be able to propose a new method to the High Representative in the selection of these representatives.

7. Within the framework of the Ministry of Commerce, private investment offices will be established to implement the provisions of this law. The powers, responsibilities and organizational chart of this office shall be specified in the regulation by the High Committee.

8. No export tariffs will be applied and they will be exempt from tax for four years after the start of production of the products.

9. It is stated that foreign investors can rent real estate properties for ten, twenty and thirty years in short-, medium- and long-term regarding land leasing. Leasing real estate properties is carried out pursuant to the project implementations, and the High Investment Commission can extend the leasing period of the real estate properties based on the need and the justifiable reason.

10. All of the investors, regardless of whether they are domestic or foreign, have the right to use the same standards of laws. All domestic and foreign investors benefit from incentives such as banking facilities in Afghanistan, opening of foreign currency accounts and providing loans to invest in the country.

11. Investments in the construction of pipelines, telecommunications infrastructure, oil and gas, mines and minerals and heavy industries are exempt from the provisions of this legislation. Investments in these sectors will be regulated under separate legislation (http://investmentpolicyhub.unctad.org/InvestmentLaws/laws/2. Access: 20.08.2018).

As a result, entrepreneurship, which keeps in the background of the policies aimed at solving problems and safety needs within the state itself, has attracted more attention and been considered important since 2012 in the country. The state has attempted to improve the economy by taking measures and with the support it has tried to implement in order to increase the number of women entrepreneurs and to prevent drugs and unregistered employment.

In particular, it have been very important for Afghanistan's entrepreneurship and economy that foreign investors (such as moving Coca-Cola's bottling plant from Dubai to Kabul) have moved their initiatives to the country in recent years due to the cheap labor and low-cost investments resulting from the overpopulation in Afghanistan (Holling Center, 2011: 3). Moreover, considering that the food and beverage market in Afghanistan is expected to reach $\$ 100$ million in 2050 (Holling Center, 2011: 3), this may indicate a significant potential for the development of entrepreneurship in Afghanistan.

\section{Research Purpose And Scope}

Afghanistan is one of the countries with the richest civilizations in the world. However, Afghanistan cannot develop and get a place in the world economy and business world due to a number of political risks. Many countries around the world are looking for different ways and making efforts to strengthen their economies. One of the most important activities that will contribute to the growth and development of Afghanistan is to give importance to entrepreneurship and entrepreneurial incentives that will increase the share of the private sector in the economy like other countries in the world. There are social, economic, political, cultural and security problems ahead of entrepreneurship for domestic and foreign investors in Afghanistan. Measures to be taken to solve these problems and contribute to the development of the country will elevate the place of Afghanistan in the international indices. To this end, the study aims to determine what needs to be done to develop entrepreneurship by pointing out the effects of the scores of the international indices of Afghanistan on each other and drawing attention to the activities used in the calculation of the indices. Accordingly, the scope of the research consists of the scores of four international indices (Ease of Doing Business Index, Information and Communication Technology Development Index, E-Government Development Index and Logistics Performance Index) of Afghanistan, which are considered to be related to entrepreneurship.

\section{Research Model And Hypotheses}

Entrepreneurial activities are shaped by many national and international factors in any country. The countries should be able to analyze the conditions and possibilities they have while aiming to increase their private sector investments that will strengthen their economies. Hence, the international indices give us an opportunity to assess the countries economically, socially and politically, and to compare them with other countries. 
Most of these indices published by different international organizations do not have a regular course. Considering the Ease of Doing Business Index as a dependent variable, which evaluates the economies of the countries according to the standards of having the appropriate environment for doing business, other indices that affect this index are considered as independent variables, and the following model and 3 hypotheses related to this model have been formed in order to determine the investments that will support entrepreneurship.

Figure 1: Research Model

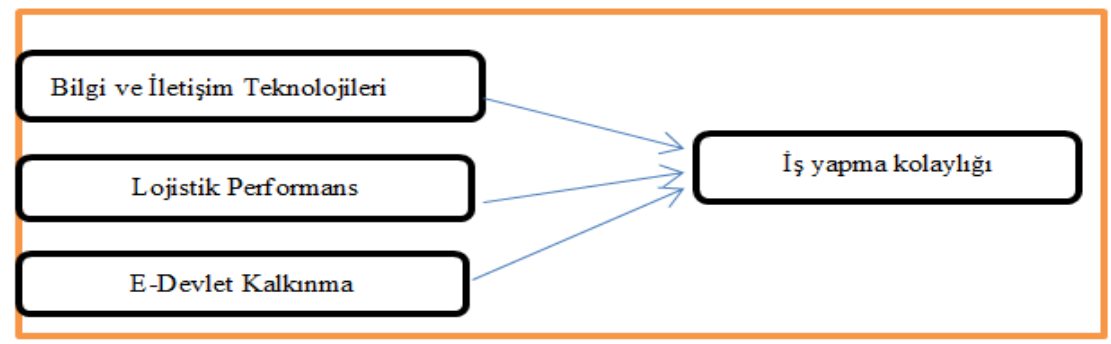

$1 \mathrm{H1}$ : Information and Communication Technologies have a significant positive effect on the Ease of Doing Business. 2 H1: Logistics Performance has a significant positive effect on the Ease of Doing Business.

3 H1: E-Government Development has a significant positive effect on the Ease of Doing Business.

\section{Research Methodology}

The study was tried to assess the level of effect of the E-Government Development Index, Logistics Performance Index and Information and Communication Technology Index on the ease of doing business within the framework of the Ease of Doing Business Index with simple linear regression analysis. Most of these indices published by different international organizations do not have a regular course. Therefore, the figures of 2016, which include index data for the same year, constitute the data source of our study. To this end, it was reached to the data of 2016 of the indices specified via Turkish Statistical Institute (TSI) and it was determined to include 193 countries in the E-Government Development Index, 160 countries in the Logistics Performance Index, 176 countries in Information and Communication Technology Development Index and 190 countries in the Ease of Doing Business Index. When the data set was created, the countries which could not provide data and were not evaluated in 2016 were eliminated, so that it consisted of 145 countries.

\section{Research Findings}

The data obtained from TSI were evaluated by using SPSS 22.0 statistical package program and the results were interpreted. First of all, correlation analysis was carried out to determine whether the relationships considered to be theoretically significant between the variables included in the research model were statistically significant. Then, simple linear regression analysis was applied to test the causality relationship between the E-government Development level measuring the willingness and capacity of the national administrations to use information and communication technologies in the provision of public services, and the Logistics Performance level evaluating the performances of the countries in the logistics areas such as customs, transportation and infrastructure, and the Information and Communication Technology Development level showing the level of using Information and Communication technologies, which are thought to be effective on the ease of doing business, and the obtained results were interpreted. Lastly, the place of Afghanistan was tried to be determined among 145 countries with the cluster analysis.

\subsection{Correlation Analysis}

It is possible to use the Pearson correlation coefficient if the data are measured with intermittent or proportional scale (Yukselen, 2006: 129). Pearson correlation coefficient is used to measure the degree of linear relationship of two continuous variables (Kalayci, 2010: 116).

Table 1: Pearson Correlation Coefficient Analysis Results Between Variables

\begin{tabular}{llcccc}
\hline \multicolumn{1}{c}{ Variables } & $\mathbf{1}$ & $\mathbf{2}$ & $\mathbf{3}$ & $\mathbf{4}$ \\
\hline $\mathbf{1}$ & BITG & 1 & & & \\
$\mathbf{2}$ & E-GOVERNMENT & $0.833^{*}$ & 1 & 1 & 1 \\
$\mathbf{3}$ & LOGISTICS & $0.751^{*}$ & $0.672^{*}$ & $0.702^{*}$ & 1 \\
$\mathbf{4}$ & TRANSACT & $0.835^{*}$ & $0.724^{*}$ & & \\
& BUSINESS & & & & \\
\hline
\end{tabular}

*Correlation is significant at 0.01 level. 
According to Table 1, the same directional and high strong linear relationship was found between the Information and Communication Technologies and E-Government Development levels ( $\mathrm{r}=0.833)$, the Information and Communication Technologies and Logistics Performance levels ( $\mathrm{r}=0.751)$ and the Information and Communication Technologies and Ease of Doing Business levels ( $\mathrm{r}=0.835$ ).

Likewise, the relationship between the E-Government index and Logistics Performance levels was seen to be same directional and moderate linear $(r=0.672)$, that of the E-Government Development index levels and Ease of Doing Business index was found to be same directional and high strong linear ( $\mathrm{r}=0.724)$.

The relationship between the Logistics Performance levels and Ease of Doing Business levels was also found to be same directional and high strong linear $(\mathrm{r}=0.702)$.

Table 1 shows there is the strongest relationship between the ease of doing business and information and communication technologies. The second strongest linear result is the relationship between the E-government development and information communication development levels.

\subsection{Regression Analysis}

Regression analysis is carried out to determine the relationship between two or more variables which have a causeeffect relationship and to use this relationship to make estimation or prediction.

The results of the regression analyses applied at $95 \%$ confidence limit for testing the hypotheses developed within the scope of the variables of the research model are as follows.

Table 2 shows a model summary of the causality relationship between the level of information and communication technologies and the ease of doing business. The value of R2 needs to be examined. Based on this result, the percentage change in the dependent variable is explained by the independent variable included in the model (Kucuksille, 2010: 203). In other words, $69.7 \%$ of the change in the levels of ease of doing business is explained by the changes in Information and Communication Technology development.

Table 2: Information and Communication Technologies Ease of Doing Business Model Summary

\begin{tabular}{ccc}
\hline Model & $\mathbf{R}$ & $\mathbf{R}^{2}$ \\
\hline 1 & 0.835 & 0.697 \\
\hline
\end{tabular}

Table 3 shows the estimated values of the coefficients in the model and the corresponding $t$ values.

Table 3: Information and Communication Technologies Ease of Doing Business Model Summary

\begin{tabular}{cccc}
\hline Model 1 & B & t & P \\
\hline Fixed & 38.578 & 26.639 & 0.000 \\
BITG & 4.841 & 18.129 & 0.000 \\
\hline
\end{tabular}

The regression equation of the Information and Communication Technology development and ease of doing business variables is written as (Ease of Doing Business $=38.578+4.841 *$ Information Processing Technologies). Table 3 shows that 1 unit of development in information and communication technologies will increase 4.841 units in the ease of doing business levels of the countries.

The coefficient of the information and communication technologies variable is statistically significant in case of $\mathrm{p}=$ $0.000<0.05$ for these variables. Therefore; $1 \mathrm{H} 0: \beta 1=0,1 \mathrm{H} 1$ : The hypothesis $1 \mathrm{H} 0$ was rejected and the hypothesis $1 \mathrm{H} 1$ was accepted from the hypotheses established as $\beta 1 \neq 0$. Hence, it can be said that developments in information and communication technologies have a significant effect on the ease of doing business. The correlation coefficient table also showed a high positive relationship between the two variables. Therefore, it can be said that the countries, which provide to develop information and communication technologies and can increase the use of these technologies, will reach to a better level in terms of ease of doing business and thus will be attractive for investors.

Table 4 shows a model summary of the causality relationship between the logistics performance and ease of doing business. $49.3 \%$ of the change in the level of ease of doing business is explained as changes in logistics performance development in the value of R2 needed to be examined.

Table 4: Logistics Performance - Ease of Doing Business Model Summary

\begin{tabular}{ccc}
\hline Model & $\mathbf{R}$ & $\mathbf{R}^{2}$ \\
\hline 1 & 0.702 & 0.493 \\
\hline
\end{tabular}


Table 5 shows the estimated values of the coefficients in the model and the corresponding t values.

Table 5: Logistics Performance - Ease of Doing Business Model Summary

\begin{tabular}{cccc}
\hline Model 1 & B & t & P \\
\hline Fixed & 19.557 & 5.254 & 0.000 \\
LOGISTICS & 14.754 & 11.797 & 0.000 \\
\hline
\end{tabular}

Logistics Performance level and Ease of doing business equation is defined as (ease of doing business $=19.557+$ 14.754 *Logistics Performance). Table 5 shows that 1 unit of change in Logistics performance will increase 14.754 units in the ease of doing business levels.

The coefficient of Logistics performance variable is statistically significant in case of $p=0.000<0.05$ for these variables. Therefore; $2 \mathrm{H} 0: \beta 1=0,2 \mathrm{H} 1$ : The hypothesis $2 \mathrm{H} 0$ was rejected and the hypothesis $2 \mathrm{H} 1$ was accepted from the hypotheses established as $\beta 1 \neq 0$. From this point of view, it is seen that the developments in the level of Logistics performance have a significant effect on the ease of doing business. Correlation coefficient table also shows that there is a high positive relationship. This can be explained by the fact that countries which increase and improve their logistics performance will move more easily and further increase their efficiency.

Table 6 shows a summary of the causality model on E-Government Development and Ease of Doing Business Model. According to the value of R2, 52.4\% of the change in the level of ease of doing business is explained as the changes in the E-Government development.

Table 6: Use of E-Government - Ease of Doing Business Model Summary

\begin{tabular}{ccc}
\hline Model & $\mathbf{R}$ & $\mathbf{R}^{2}$ \\
\hline 1 & 0.724 & 0.524 \\
\hline
\end{tabular}

Table 7 shows the estimated values of the coefficients in the model and the corresponding $t$ values.

Table 7: Use of E-Government - Ease of Doing Business Model Summary

\begin{tabular}{cccc}
\hline Model 1 & B & t & P \\
\hline Fixed & 39.586 & 20.039 & 0.000 \\
E-GOVERNMENT & 43.693 & 12.536 & 0.000 \\
\hline
\end{tabular}

Regression equation is written as (Ease of doing business $=39.586+43.693 *$ Use of E-government) based on the use of E-Government and Ease of doing business variables. Table 7 shows that 1 unit of E-government development will increase 43.693 units in the ease of doing business.

The coefficient of E-state development variable is statistically significant in case of $\mathrm{p}=0.000<0.05$ for variables. $3 \mathrm{H} 0$ : $\beta 1=0,3 \mathrm{H} 1$ : The hypothesis $3 \mathrm{H} 0$ was rejected and the hypothesis $3 \mathrm{H} 1$ was accepted from the hypotheses established as $\beta 1 \neq 0$. The hypothesis $3 \mathrm{H} 1$ was accepted. Based on these coefficients, there is a positive and significant relationship between two variables. As E-Government development increases, it is concluded that countries make their work easier, more efficient and profitable.

\subsection{Cluster Analysis}

Cluster analysis is one of the multivariate statistical methods frequently used to classify grouped data according to their similarities.

As the number of groups was determined according to the development levels of countries in the study and three groups were created as developed, developing and underdeveloped countries, the K-means clustering technique, one of non-hierarchical clustering methods, was used and the number of repetitions was determined as 10 and the convergence criterion was also determined as 0.2 from the literature. Cluster analysis was performed within the framework of variables such as ease of doing business, levels of logistics performance, levels of e-government development and levels of development of information and communication technologies.

Table 8: Cluster Analysis

\begin{tabular}{lll}
\hline \multicolumn{1}{c}{ CLUSTER 1 } & \multicolumn{1}{c}{ CLUSTER 2 } & \multicolumn{1}{c}{ CLUSTER 3 } \\
\hline Afghanistan & Argentina & Germany \\
Angola & Albania & United States \\
Bangladesh & Bahamas & Australia \\
Benin & Bahrain & Austria \\
Bolivia & Bosnia and Herzegovina & Belgium \\
Burkina Faso & Botswana & United Arab Emirates \\
Burundi & Brasilia & United Kingdom (England)
\end{tabular}




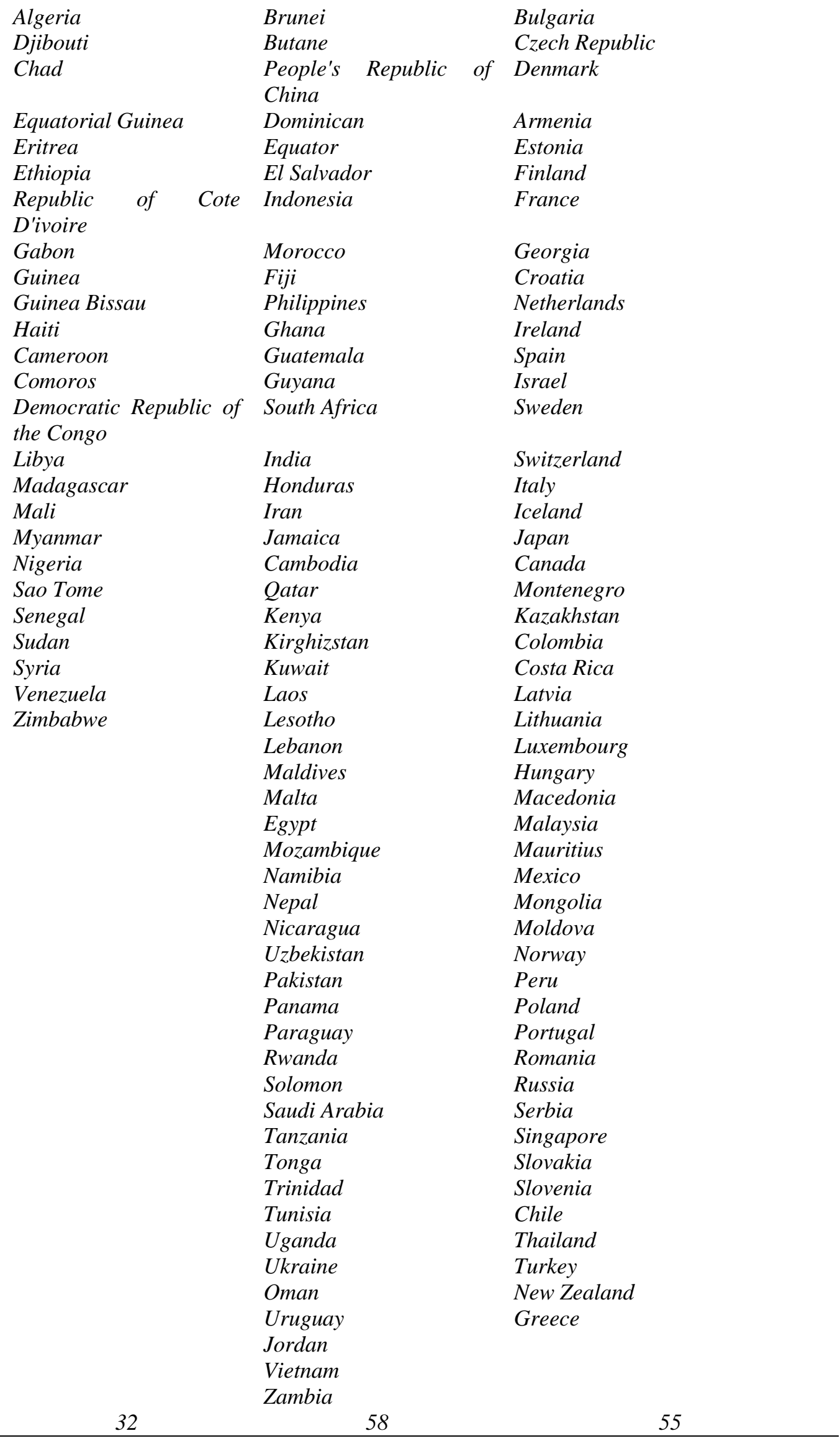


Given the cluster distributions obtained as a result of the cluster analysis, they are evaluated under the categories as follows: the 1st Cluster is underdeveloped countries, the 2nd Cluster is developing countries and the 3rd Cluster is developed countries. Afghanistan is seen to be in the group of underdeveloped countries based on the variables addressed with the other 31 countries. Afghanistan has 0.2313 of E-Government Development Index Score in terms of ease of doing business and it is ranked 168th out of 193 countries in this index. Afghanistan is ranked 165th out of 176 countries with the index score of 1.71 in Information and Communication Technology Development Index. According to the Logistics Performance index, it is ranked 150th out of 160 countries with the index score of 2.14. For the Ease of Doing Business Index, it was ranked 18th out of 190 countries with the score of 40.58. Afghanistan is confirmed to be included at the 1 st cluster of underdeveloped countries within the scope of these index scores.

As a result of all these indices, Afghanistan, which is located at the end of the list, is not attractive for the investors and entrepreneurs. It seems very difficult for investors to invest in non-attractive Afghanistan in case where it is ranked 183th out of 190 countries.

As a result of the civil war and terrorist attacks experienced in the development of the state, Afghanistan has not developed and has kept foreign investors away from itself.

There is also a lack of confidence in logistics because of the terror encountered. The country uses only land and air transportation since it does not have seashore. Due to the war happened in the country, a very safe transportation system is not possible; logistics development cannot be provided because of troubles not to be prevented.

Nevertheless, the information and communication technologies in the country have not developed as a result of the infrastructure problems caused by the wars. Even though the infrastructure works of the country have been made with the support of the state from time to time, no significant progress can be observed due to the ongoing war. Therefore, it is not possible to talk about communication and information technology throughout the country.

In the light of all these analyses, foreign investors look at some basic principles in the countries where they will invest. Some of these are the stability, security and management quality of the country. Since none of them have been provided in Afghanistan yet, it is not possible to talk about entrepreneurship and ease of doing business.

\section{Conclusion And Recommendations}

Entrepreneurship is an important concept for many countries. The strong economy can enable the countries to reach the high level of development and prosperity and their entrepreneurial activities are the most important weapon of their powerful economies. For Afghanistan, which has an important place for the Middle East, entrepreneurial activities are indispensable and vitally important. Afghanistan has been of great value to the great powers because of its natural resources throughout its history. Thus, internal and ethnic conflicts have occurred in the country occasionally resulting from internal dynamics and sometimes external factors. Afghanistan has been exposed to internal conflicts or external interventions from past to present and has not developed in the economic sense due to its different ethnic groups and geopolitical location.

The study examined the place of Afghanistan in international indices and addressed its place in four indices which are particularly considered to be effective in entrepreneurial investments which will strengthen the economy. According to the current figures, it is ranked 177st in the Ease of Doing Business Index in 2016, 18th in the Ease of Doing Business Index in 2017 and 18th in the Easy of Doing Business Index in 2018. It is ranked 159th in the Information and Communication Technology Index in 2017 and 177th in the E-Government Development Index in 2018. It is ranked 150th in the Logistics Performance Index in 2016 and 160th in the Logistics Performance Index in 2018. Since the years in which the indices were calculated were not compatible with each other, the relationships of four indices were examined by taking account of the scores of the Ease of Doing Business, Information and Communication Technology Development, E-Government Development and Logistics Performance indices in 2016, and performing correlation analysis. As a result of analysis, the presence of the relationship between the four indices (ICT and E-Government: 0.833; ICT and Logistics: 0.751; ICT and Doing Business: 0.835; E-Government and Logistics: 0. 672; E-Government and Doing Business: 0.724; Logistics and Doing Business: 0.702) was observed.

Three hypotheses were formed and linear regression was performed to test these hypotheses within the scope of the research. The hypothesis $1 \mathrm{H}_{1}$ was accepted and it was seen that investments in information and communication technologies increased the ease of doing business significantly and positively. Similarly, the hypothesis $2 \mathrm{H}_{1} \mathrm{was}$ also tested and the hypothesis $2 \mathrm{H}_{1}$ was also accepted with the understanding that logistics performance increased the ease of doing business significantly and positively. The third and final hypothesis $3 \mathrm{H}_{1}$ of the study was also accepted and it was observed that E-Government development investments had a significant and positive effect on the ease of doing business. 
Finally, cluster analysis was included in the study. 145 countries with healthy data of 2016 were divided into three groups and Afghanistan took place the group of "Underdeveloped Countries". The fact that Afghanistan is ranked 183th in the index especially in terms of the ease of establishing a business show that it is a country that is not preferred for investment and has not achieved economic development.

There are wars, security problems as well as the lack of educated population in Afghanistan among the reasons why it is an underdeveloped country. Therefore, the government in particular needs to urgently make structural reforms and ensure the security of the country It is very important to implement the measures taken to promote domestic and foreign entrepreneurship in the country. On the other hand, in the country where only the literacy rate is only $30 \%$, the education should be given in a healthy way or the opportunities should be provided to young people to enable them to receive education in developed countries. Because the importance of knowledge is increasing, which directs everything and has become one of the most important production factors. Therefore, it should be ensured to fulfill the required functions such as the collection, stocking, accessing and sharing of information globally in Afghanistan.

The main economic policy of Afghanistan whose economy is dependent on outside financial sources is based on the provision of external assistance and foreign investment. Investments and external financial assistance in the country should be used in the most efficient way to provide them to be used for the growth and development of the private sector.

It can be aimed that Afghanistan, one of the underdeveloped countries in the analyses, increases the security and infrastructure investments of the state, accelerate the technological investments and prioritize the importance given to the workforce and goes into the 2nd cluster, in other words, to become a developing country. On the other hand, it is also necessary to make life easier and to ensure security of life as well as ease of doing business in order to enable the personnel being professional and qualified required for the implementation of the desired investments to prefer Afghanistan.

This study is important in terms of being a guide to determine the investments and supports that will make the economy of Afghanistan stronger with entrepreneurial support. However, the most important limitation of the study is to be limited to only four indices, which Afghanistan also takes place within international indices and which are thought to contribute to entrepreneurship. It is thought that the recurrence of this study, which was carried out with the data of 2016 before, with future data may contribute to monitoring the development of Afghanistan in terms of both economy and entrepreneurship.

\section{Kaynakça}

Bird, B. (1998). Implementing Entrepreneurial Ideas: The Case for Intention. Academy of Management Review, Vol.13 : 442-453

Coulter M. (2001), Entrepreneurship İn Action, PrenticeHallInc., New Jersey.

Demiroğlu, Y. (2007). Firma davraniş olarak girişimcilik Dokuz Eylül Üniversitesi Sosyal Bilimler Enstitüsü işletme Anabilim Dalı Yönetim Organizasyon Programi (Yayımlanmamış Yüksek Lisans Tezi ) İzmir.

Haidary, A. (2016). Comparativeanalysis of Afghanistan'sandPakistan'sprocesses of state-buildingthesis İstanbul Aydin UniversityInstitute Of SocialSciencesDepartment of PoliticalScienceAnd International RelationsPoliticalscienceandinternationalRelations Program (YayımlanmamişYüksek Lisans Tezi). İstanbul

Haqzoy, A. A. (2017). Impact Of Foregin Direct InvestmentIn Host CountryCase Of TelecommunicationInAfghanistan: Istanbul Aydin University Institute Of Social Sciences: Department of Business Business Administration Program Thesis (Yayımlanmamış Yüksek Lisans Tezi). İstanbul

Holling Center, (2011). Afganistan-ABD İlişkilerinin Geleceği: Kalkınma, Yatırım ve Kültürel İşbirliği Diyalog Toplantis1 Raporu, s. 2.

Horizons, (2005 ). Benchmarking FDI Opportunities Investment: Afghanistan a Study of Foreign Direct Investment Costs and Conditions in Four Industries s 52-53

Kabil Ticaret Müşavirliği, (2017). Afganistan ülke raporu, s. 19, https://www.kutso.org.tr/wp-content/uploads/2017/06/Afganistan.pdf, 12.03.2018 tarihinde erişilmiştir.

Kalaycı, I. ( 2010) Piyasa ekonomisinin iki zayıf noktası: Afganistan ve Kırgızistan, Manas Sosyal Araştırmalar Dergisi, 360

Küçüksille, B. (2010) Spss uygulamalı Çok Değişkenli İstatistik Teknikleri

Mueller, S. L.,\& Thomas, A. S. (2000). Cultureandentrepreneurialpotential: A nine countrystudy of locus of controlandinnovativeness. Journal of Business Venturing, 16, 51-75. 
OfficialGazette No. 869,Law on domesticandforeignprivateinvestment in afghanistan, general provisions(http://investmentpolicyhub.unctad.org/InvestmentLaws/laws/2, [Online] Available: August 20, 2018.

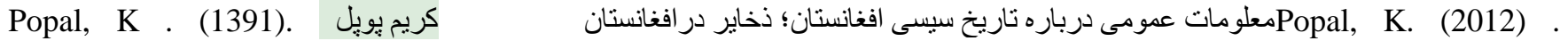
(http://horiatsiasat.blogspot.com).[Online] Available: August 20, 2018.

TÜIK,http://www.iccwbo.org/global-influence/g20/reports-and-products/open-marketsindex/[Online] Available: August 25, 2018.

USAID, (2018). Ekonomicsgrowthontactinformationmissioncontactusaid/Afghanistan Great Masood Road Kabul, Afghanistan Kabul Afghanistanhttps://www.usaid.gov/afghanistan[Online] Available: June13, 2018.

Yükselen, C. (2006) Pazarlama Araştırmaları Detay Yayıncılık Ankara.

https://www.aydinlik. com.tr/, [Online] Available: March18, 2018). 